\title{
MARINE POLLUTION OF HADRAMOUT COAST BY HEAVY ELEMENTS
}

\author{
M.S.H.Al-Kahali*, A.A. Ba-Isa* and N.A. Al-Shawafi** \\ *Department of Chemistry and **Department of Earth Science \& Environment, \\ College of Science, Sana'a University, Yemen.
}

\begin{abstract}
:
The concentrations of trace elements in a studied area along the coast of Hadramout were determined. This paper is an exclusive study which covers the sediments, sea water, and tar balls in five sites, extending a length of around $200 \mathrm{~km}$ along the Hadramout coast. The concentrations of trace elements obtained in this study have increased remarkably compared with previous measurements ${ }^{[1]}$. Despite the increase in concentrations, the environmental hazard is not considered to be a threat to marine wildlife.
\end{abstract}

\section{INTRODUCTION :}

Marine environment is considered to be as one of the most important habitat that must be protected from pollution worldwide. Since most of the population of the world, in particularly poorer countries depend for their protein diet on the wildlife of the oceans.

In recent years marine pollution has increased noticeably, due to the increase in ship traffic and the uncontrollable dumping of toxic materials and wastes to the ocean.

Many countries and environmental agencies have expressed their great concern to the pollution of their marine environment along their coasts, and territorial waters. The blame was directed to the industrial and developed countries, that think of profits only without consideration to the safety of the environment.

In fact, some industrially developed countries dump their wastes along the coast of underdeveloped countries, escaping the rising criticism of the environmental non-government agencies in their own countries. Together, the poor resources and the corruption that the underdeveloped countries suffer from, helps those companies who dump their wastes in the backyard of the poorer countries get away without being apprehended and punched for their deed.

This work deals with the occurrence and distribution of heavy elements $(\mathrm{Cd}, \mathrm{Co}, \mathrm{Pb}, \mathrm{Cr}$, $\mathrm{Fe}, \mathrm{Ni}, \mathrm{Cu}, \mathrm{Zn}, \mathrm{Mn}$, and $\mathrm{V}$ ) along the coast in the hadramout month of October 2000.

\section{MATERIAL AND METHODS :}

The area under investigation is shown in Fig. (1). It extends from west of Broom to east of Al-Shaher (about $200 \mathrm{Km}$ ). Five sampling sites were chosen to represent different parts of hadramout coast (Fig. 1). 


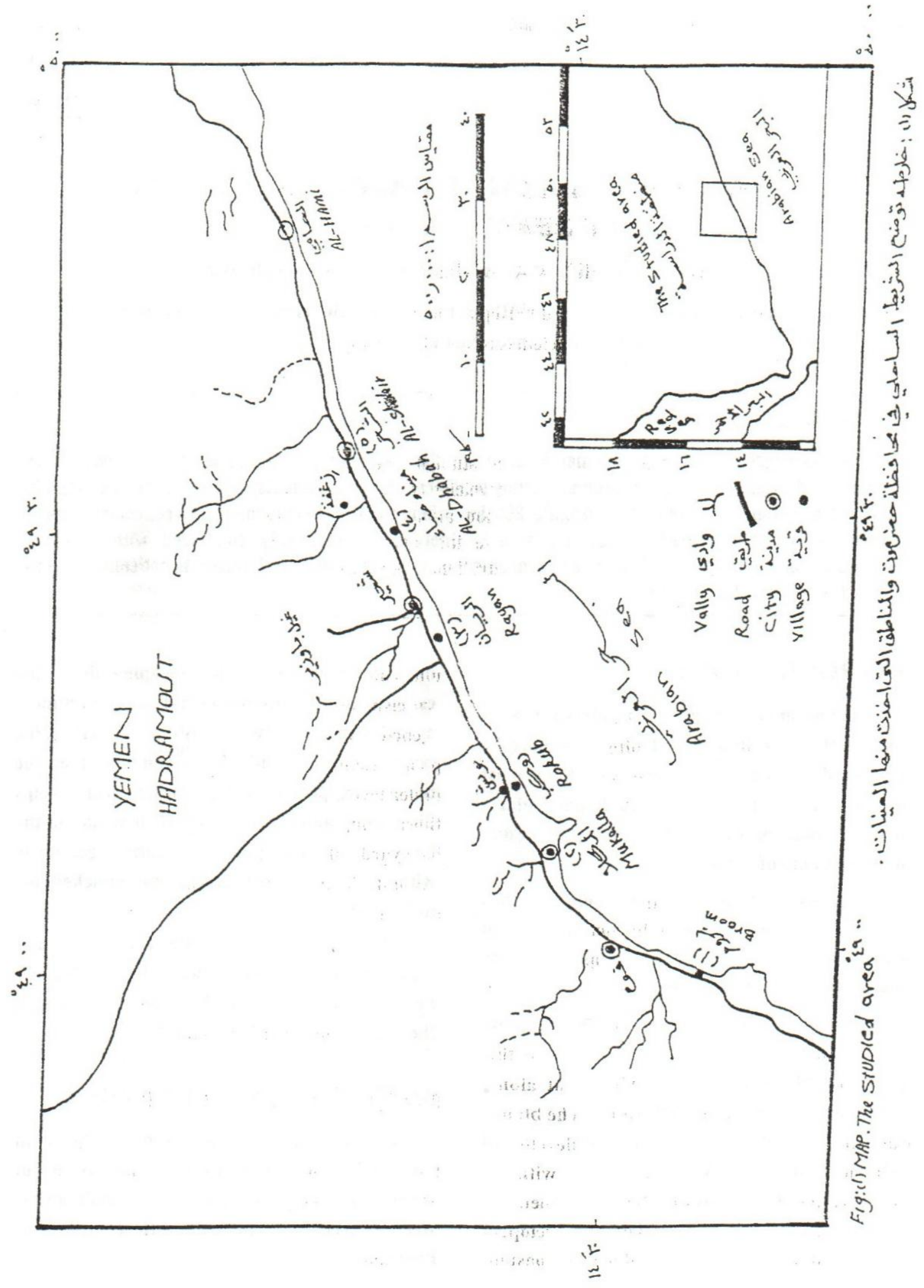




\section{Water Samples :}

Surface water samples from each station were collected (about $10 \mathrm{~cm}$ below the surface to avoid floating materials) directly into 2.5 litres polyethylene bottles, cleaned by and acid $(6 \mathrm{M}$ $\mathrm{HNO}_{3}$ ) and rinsed with deionised water. Samples were placed in ice and transported to the laboratory and stored in deep freezer until analysed. Temperature, $\mathrm{pH}$ and conductivity (EC) of water were recorded at sampling time. The samples were filtered through 0.45 um pore size Millipore filters. The filtered water was allowed to pass through a glass column, containing the ammonium form of Chelex-100 resin to preconcentrate the dissolved elements ${ }^{[2]}$. The metals on the resin were eluted with silica distilled $2 \mathrm{M} \mathrm{HNO}_{3}$ and evaporated to near dryness. One $\mathrm{ml} 6 \mathrm{M} \mathrm{HNO}_{3}$ was added to dissolve the metals in the residue and made up the solution to $25 \mathrm{ml}$ using deionised water.

\section{Sediment Samples :}

The sediments were collected at five sites shown in Fig. (1), using stainless steel Ekman's grab. Every sample was well mixed after being freed from coarse shell fragments and visible sea grass leaves when present. A $200 \mathrm{~g}$ of the sediment was transferred to self-sealing plastic bag. Then, about $20 \mathrm{~g}$ of the sample was dried at $80^{\circ} \mathrm{C}$ in silica basin, and then grounded in an agate mortar. One gram of the dry sediment was digested with $25 \mathrm{ml} 2 \mathrm{M} \mathrm{HNO}_{3}{ }^{[3]}$ on a hot plate for four hours. The content was evaporated to near dryness. One $\mathrm{ml} 6 \mathrm{M} \mathrm{HNO}_{3}$ was added to dissolve the metals in the residue and the solution was made up to $25 \mathrm{ml}$ using deionised water.

\section{Tar Balls Samples :}

One square kilometer of coastline was selected at each station. The dimensions of which were $250 \mathrm{~m}$ in length and $4 \mathrm{~m}$ in width. This area was divided into five transects $(\mathrm{A}, \mathrm{B}$, C, D, E) three of which $(\mathrm{A}, \mathrm{C}, \mathrm{E})$ whose areas are $200 \mathrm{~m}^{2}$ each were chosen for tar balls collection thus the area sampled at each was 600 $\mathbf{m}^{2}$. Tar balls were collected carefully by hand, loose sand, coral or other materials attached to them were removed. Then tar balls were washed, dried in an open air, raped with aluminum foil and put in plastic bag. The weight of tar balls was determined to the nearest $0.1 \mathrm{~g}$, then from the weight of tar balls and area of the transects sampled the amount and number of tar balls per square meter of beach was calculated.

\section{Preparation of the tar balls solution for analysis :}

A quantity of $5.0 \mathrm{~g}$ of tar balls sample was dissolved in $50 \mathrm{ml}$ of pure chloroform to obtain a clean solution of the tar balls. Glass Fiber

Filter (GFF) was used to remove any particulate from the solution. The filtrate was heated using water bath at $40^{\circ} \mathrm{C}$ until dryness. Two grams of cleaned tar balls sample for the analysis of trace elements $^{[4]}$ were dissolved in $1.5 \mathrm{ml}$ of pure concentrated perchloric acid and $4.5 \mathrm{ml}$ of concentrated nitric acid. The solution was sealed and allowed to predigest overnight. Then the solution was placed over a water bath set at $70^{\circ}$ $C$ for 2 hours until the solution was clear. Then, 2 to $3 \mathrm{ml}$ of deionised water was added. The solution was reheated on a hot plate at $70^{\circ} \mathrm{C}$, to reduce the solution to 1 to $2 \mathrm{ml}$. Then transferred to a $50 \mathrm{ml}$ volumetric flask and the final volume made up to $50 \mathrm{ml}$ by deionised water. The final step involves the quantitative determination of the trace elements by using Atomic Spectrophotometer (AAS-Perkin Elmer, Model 2380) and UV/VIS Spectrophotometer (PYE UNICAM, Model PU 8800). All standards used 
in the present study were spectro grade supplied by Merk.

\section{RESULTS AND DISCUSSION :}

\section{Oceanographic Parameters:}

Certain parameters of relevance were measured in the field such as : $\mathbf{p H}$, temperature, electroconductivity (EC) and total dissolved solids (TDS), which could help on the assessments and give us an indication on how much the coast is polluted.

The $\mathrm{pH}$ values, temperature, electroconductivity (EC), and total dissolved solids (TDS), for the five cites were recorded on the $14^{\text {th }}$ of October 2000 (Table 1). The pH values fluctuate in the range 7.9 at $\mathrm{Al}-\mathrm{Dhabah}$ and $\mathrm{Al}-\mathrm{Shaher}$ to 8.1 at Al-Rayan. These $\mathrm{pH}$ values are similar to those obtained previously for the sea waters of the Red Sea and the Gulf of $\operatorname{Aden}^{[5]}$.The temperature values recorded show slight decrease from previously recorded temperature ${ }^{[6]}$, this was due to the cooler temperatures in October. The mean electroconductivity (EC) of the sea water samples was 51.0 mmole, slightly lower than those obtained in March $^{[1]}$. The total dissolved solids (TDS) were calculated from the electroconductivity (EC) values.

Table (1): Temperature, $\mathrm{pH}$ and EC of water samples.

\begin{tabular}{|c|l|c|c|c|c|}
\hline \hline No & Location & PH & T $^{\circ} \mathrm{C}$ & EC mmoles & TDS mg $/$ \\
\hline 1 & Broom & 8.0 & 28 & 51.0 & 33.50 \\
2 & Al-Mukalla & 8.0 & 27.5 & 51.0 & 33.50 \\
3 & Al-Rayan & 8.1 & 27 & 51.0 & 33.50 \\
4 & Al-Dhabah & 7.9 & 28.5 & 51.0 & 33.50 \\
5 & Al-Shaher & 7.9 & 28.5 & 51.0 & 33.50 \\
\hline
\end{tabular}

\section{Trace Elements in Sea Water :}

Table (2) show the concentrations of trace metal ions in sea water samples from the five sites, expressed in ppb. The mean concentrations for $\mathrm{Cd}, \mathrm{Co}, \mathrm{Cr}, \mathrm{Pb}$, and $\mathrm{Fe}$ are $0.800,0.306,0.074,0.065$, and 0.065 ppb respectively. The concentrations give minor variations for $\mathrm{Cd}, \mathrm{Cr}, \mathrm{Pb}$, and $\mathrm{Fe}$, and major variations for $\mathrm{Co}$, for all the five sites studied. While the mean concentrations for $\mathrm{Mn}, \mathrm{Ni}, \mathrm{Cu}$, $\mathrm{Zn}$, and $\mathrm{V}$ are $0.027,0.054,0.042,0.034$ and $0.046 \mathrm{ppb}$ respectively. These variations are related to the different amounts of anthropogenic inputs such as oil pollution and untreated sewage.

Table (2): The Concentration of the trace elements in Sea Water samples (ug/l $1=p p b)$.

\begin{tabular}{||l|c|c|c|c|c|c|c|c|c|c||}
\hline \multicolumn{1}{|c|}{ Location } & $\mathrm{Cd}$ & $\mathrm{Co}$ & $\mathrm{Mn}$ & $\mathrm{Cr}$ & $\mathrm{Pb}$ & $\mathrm{Fe}$ & $\mathrm{Ni}$ & $\mathrm{Cu}$ & $\mathrm{Zn}$ & $\mathrm{V}$ \\
\hline Broom & 0.850 & 0.080 & 0.030 & 0.082 & 0.063 & 0.078 & 0.051 & 0.044 & 0.029 & 0.040 \\
Al-Mukalla & 0.890 & 0.600 & 0.015 & 0.085 & 0.055 & 0.035 & 0.060 & 0.040 & 0.028 & 0.039 \\
Al-Rayan & 0.750 & 0.700 & 0.013 & 0.060 & 0.055 & 0.078 & 0.043 & 0.030 & 0.037 & 0.040 \\
Al-Dhabah & 0.800 & 0.085 & 0.050 & 0.090 & 0.080 & 0.083 & 0.070 & 0.055 & 0.030 & 0.060 \\
Al-Shaher & 0.700 & 0.063 & 0.025 & 0.055 & 0.073 & 0.050 & 0.047 & 0.040 & 0.047 & 0.050 \\
\hline Mean & 0.800 & 0.306 & 0.027 & 0.074 & 0.065 & 0.065 & 0.054 & 0.042 & 0.034 & 0.046 \\
Medium & 0.800 & 0.085 & 0.025 & 0.082 & 0.063 & 0.058 & 0.051 & 0.040 & 0.030 & 0.040 \\
\hline
\end{tabular}


As obvious in the present work the concentration of $\mathrm{Cd}$ and Co were higher from that obtained in previous work ${ }^{(1)}$ on the same five sites. In fact, for $\mathrm{Cd}$ the present result fit into the results obtained by Bryan ${ }^{[7]}$, for Bristol Channel, a busy and very polluted channel. While the concentration for $\mathrm{Co}$ in the present work was not recorded previously as that high by Bryan ${ }^{[7]}$, and Riley \& Chester ${ }^{[8]}$.

A simple linear regression analysis was carried out for the data obtained in this work. The result of these analyses for the dissolved trace elements concentrations are presented in Table (3), in the form of correlation coefficients. The results show higher values of correlation coefficients for the trace elements pair $\mathrm{Pb}-\mathrm{V}$, and $\mathrm{Mn}-\mathrm{Cu}$.

\section{Trace Elements in The Sediments :}

The concentrations of trace elements in the sediments tend to be an order of magnitude higher than their concentrations in the overlying water column. Because the sediments act as a trap for different elements, Thomas ${ }^{[9]}$. Hence concentration data of trace elements in the sediments, should give an indication and relevant sign on how much the pollution in aquatic environment has reached.

Table (3): Correlation Coefficients between two elements in sea water of Hadramout coast.

\begin{tabular}{|c|c|c|c|c|c|c|c|c|c|c|c|c|c|c|}
\hline $\begin{array}{l}\text { Cd } \\
\text { Co }\end{array}$ & $\begin{array}{l}\text { Cd } \\
\text { Mn }\end{array}$ & $\begin{array}{l}\mathrm{Cd} \\
\mathrm{Cr}\end{array}$ & $\begin{array}{l}\mathrm{Cd} \\
\mathrm{Pb}\end{array}$ & $\begin{array}{l}\mathrm{Cd} \\
\mathrm{Fe}\end{array}$ & $\begin{array}{l}\mathrm{Cd} \\
\mathrm{Ni} \\
\end{array}$ & $\begin{array}{l}\mathrm{Cd} \\
\mathrm{Cu}\end{array}$ & $\begin{array}{l}\text { Cd } \\
\mathrm{Zn} \\
\end{array}$ & $\begin{array}{l}\text { Cd } \\
\text { V }\end{array}$ & $\begin{array}{l}\text { Co } \\
\text { Mn } \\
\end{array}$ & $\begin{array}{l}\mathrm{Co} \\
\mathrm{Cr}\end{array}$ & $\begin{array}{l}\mathrm{Co} \\
\mathrm{Pb}\end{array}$ & $\begin{array}{l}\mathrm{Co} \\
\mathrm{Fe}\end{array}$ & $\begin{array}{l}\mathrm{Co} \\
\mathrm{Ni}\end{array}$ & $\begin{array}{l}\mathrm{Co} \\
\mathrm{Cu}\end{array}$ \\
\hline 0.21 & -0.76 & 0.83 & -0.39 & -0.19 & 0.50 & 0.27 & -0.93 & -0.37 & -0.76 & 0.49 & -0.83 & -0.26 & -0.27 & -0.69 \\
\hline $\begin{array}{l}\text { Co } \\
\text { Zn }\end{array}$ & $\begin{array}{l}\text { Co } \\
\mathrm{V}\end{array}$ & $\begin{array}{c}\mathrm{Mn} \\
\mathrm{Cr}\end{array}$ & $\begin{array}{l}\text { Mn } \\
\text { Pb }\end{array}$ & $\begin{array}{c}\mathrm{Mn} \\
\mathrm{Fe}\end{array}$ & $\begin{array}{l}\mathrm{Mn} \\
\mathrm{Ni}\end{array}$ & $\begin{array}{l}\mathrm{Mn} \\
\mathrm{Cu}\end{array}$ & $\begin{array}{c}\mathrm{Mn}_{\mathrm{n}} \\
\mathrm{Z}_{\mathrm{n}}\end{array}$ & $\begin{array}{c}\text { Mn } \\
\text { V }\end{array}$ & $\begin{array}{l}\mathrm{Cr} \\
\mathrm{Pb}\end{array}$ & $\begin{array}{l}\mathrm{Cr} \\
\mathrm{Fe}\end{array}$ & $\begin{array}{l}\mathrm{Cr} \\
\mathrm{Ni}\end{array}$ & $\begin{array}{l}\mathrm{Cr} \\
\mathrm{Cu}\end{array}$ & $\begin{array}{l}\mathrm{Cr} \\
\mathrm{Zn}\end{array}$ & $\begin{array}{c}\mathrm{Cr} \\
\mathrm{V}\end{array}$ \\
\hline-0.17 & -0.62 & 0.53 & 0.89 & -0.25 & 0.71 & 0.94 & -0.22 & 0.86 & 0.15 & 0.12 & 0.85 & 0.72 & 0.87 & 0.19 \\
\hline $\begin{array}{l}\mathrm{Pb} \\
\mathrm{Fe}\end{array}$ & $\begin{array}{l}\mathrm{Pb} \\
\mathrm{Ni}\end{array}$ & $\begin{array}{l}\mathrm{Pb} \\
\mathrm{Cu}\end{array}$ & $\begin{array}{c}\mathrm{Pb} \\
\mathrm{Zm}\end{array}$ & $\begin{array}{c}\mathrm{Pb} \\
\mathrm{V}\end{array}$ & $\begin{array}{l}\mathrm{Fe} \\
\mathrm{Ni}\end{array}$ & $\begin{array}{l}\mathrm{Fe} \\
\mathrm{Cu}\end{array}$ & $\begin{array}{l}\mathrm{Fe} \\
\mathrm{Zn}\end{array}$ & $\begin{array}{l}\mathrm{Fe} \\
\mathrm{V}\end{array}$ & $\begin{array}{l}\mathrm{Ni} \\
\mathrm{Cu}\end{array}$ & $\begin{array}{l}\mathrm{Ni} \\
\mathrm{Zn}\end{array}$ & $\begin{array}{l}\mathbf{N i} \\
\mathrm{V}\end{array}$ & $\begin{array}{l}\mathrm{Cu} \\
\mathrm{Zn}\end{array}$ & $\begin{array}{c}\mathrm{Cu} \\
\mathrm{V}\end{array}$ & $\begin{array}{c}\mathrm{Zn} \\
\mathrm{V}\end{array}$ \\
\hline 0.60 & 0.88 & 0.79 & 0.24 & 0.95 & 0.03 & 0.25 & -0.17 & 0.31 & 0.86 & -0.60 & 0.60 & -0.39 & 0.75 & 0.17 \\
\hline
\end{tabular}

The concentrations of trace elements obtained in the studied area are presented in Table (4). The mean concentrations for $\mathrm{Cd}, \mathrm{Co}, \mathrm{Mn}, \mathrm{Cr}$, $\mathrm{Pb}, \mathrm{Fe}, \mathrm{Ni}, \mathrm{Cu}, \mathrm{Zn}$, and $\mathrm{V}$ are $0.596,11.860$, $35.886,8.110,10.414,854.200,11.106,8.06$, 19.440 , and $1.206 \mathrm{ug} / \mathrm{g}$ respectively. The concentrations of trace elements show variations in all the five studied sites, with a noticeably higher concentrations at Al-Shaher. This may be due to that in $\mathrm{Al}$-Shaher region, there is no sewage system, and the local inhabitants dump their sewage to the coast. Hence, the higher concentrations of trace elements were due to mainly beside the untreated sewage, oil pollution as a result of the recent oil explorations. However, the overall trace elements sediment concentration variation was largely attributed to variation in mineralogy and human activities.

The results obtained in this work still indicates that the concentrations of the trace elements in the sediments of the five studied sites are too low compared to those reported previously $^{[1]}$. Although, this present study gave higher concentrations for the trace elements than those obtained previously in March 1999. The results revealed that the studied sites have not reached a pollution stage, that one might consider hazardous to the marine environment.

Since the concentrations of trace elements may be influenced by several factors and reflect 
different sources. The results were subjected to a linear regression analysis, and the correlation coefficients between trace elements pairs in the sediments are shown in Table (5), with high values for $\mathrm{Co}-\mathrm{Mn}, \mathrm{Fe}-\mathrm{V}$, and $\mathrm{Cd}-\mathrm{Mn}$.

Table (4): The concentration of the trace elements in Sediment samples (ug/g=ppm)

\begin{tabular}{||l|c|c|c|c|c|c|c|c|c|c||}
\hline \multicolumn{1}{|c|}{ Location } & $\mathrm{Cd}$ & $\mathrm{Co}$ & $\mathrm{Mn}$ & $\mathrm{Cr}$ & $\mathrm{Pb}$ & $\mathrm{Fe}$ & $\mathrm{Ni}$ & $\mathrm{Cu}$ & $\mathrm{Zn}$ & $\mathrm{V}$ \\
\hline Broom & 0.80 & 17.00 & 80.300 & 11.900 & 9.00 & 900.00 & 10.30 & 5.50 & 9.30 & 1.20 \\
Al-mukalla & 0.30 & 10.00 & 11.300 & 0.700 & 9.80 & 800.50 & 11.50 & 10.30 & 13.30 & 1.10 \\
Al-Rayan & 0.45 & 9.50 & 1.730 & 3.95 & 17.40 & 700.00 & 11.00 & 12.50 & 16.40 & 0.93 \\
Al-Dhabah & 0.73 & 9.20 & 35.100 & 3.300 & 12.90 & 920.00 & 8.50 & 1.30 & 27.10 & 1.50 \\
Al-sheher & 0.70 & 13.60 & 51.00 & 20.700 & 2.970 & 950.50 & 14.23 & 10.70 & 31.10 & 1.30 \\
\hline Mean & 0.596 & 11.86 & 35.886 & 8.110 & 10.414 & 842.20 & 11.106 & 8.06 & 19.440 & 1.206 \\
Medium & 0.7000 & 10.000 & 35.100 & 3.950 & 9.800 & 900.00 & 11.00 & 10.30 & 16.400 & 1.200 \\
\hline \hline
\end{tabular}

Table (5) : Correlation coefficients between trace elements pairs in Hadramout coast sediments.

\begin{tabular}{|c|c|c|c|c|c|c|c|c|c|c|c|c|c|c|}
\hline $\begin{array}{l}\text { Cd } \\
\text { Co }\end{array}$ & $\begin{array}{l}\text { Cd } \\
\text { Mn }\end{array}$ & $\begin{array}{l}\mathrm{Cd} \\
\mathrm{Cr}\end{array}$ & $\begin{array}{l}\mathrm{Cd} \\
\mathrm{Pb}\end{array}$ & $\begin{array}{l}\mathrm{Cd} \\
\mathrm{Fe}\end{array}$ & $\begin{array}{l}\mathrm{Cd} \\
\mathrm{Ni}\end{array}$ & $\begin{array}{l}\mathrm{Cd} \\
\mathrm{Cu}\end{array}$ & $\begin{array}{l}\text { Cd } \\
\text { Zn }\end{array}$ & $\begin{array}{c}\text { Cd } \\
\text { V }\end{array}$ & $\begin{array}{l}\text { Co } \\
\text { Mn }\end{array}$ & $\begin{array}{l}\mathrm{Co} \\
\mathrm{Cr}\end{array}$ & $\begin{array}{l}\mathrm{Co} \\
\mathrm{Pb}\end{array}$ & $\begin{array}{l}\mathrm{Co} \\
\mathrm{Fe}\end{array}$ & $\begin{array}{l}\mathrm{Co} \\
\mathrm{Ni}\end{array}$ & $\begin{array}{l}\mathrm{Co} \\
\mathrm{Cu}\end{array}$ \\
\hline 0.62 & 0.86 & 0.61 & -0.35 & 0.77 & -0.17 & 0.64 & 0.31 & 0.66 & 0.90 & 0.71 & -0.59 & 0.50 & 0.28 & -0.38 \\
\hline $\begin{array}{l}\text { Co } \\
\text { Zn }\end{array}$ & $\begin{array}{c}\text { Co } \\
\text { V }\end{array}$ & $\begin{array}{l}\mathrm{Mn} \\
\mathrm{Cr}\end{array}$ & $\begin{array}{c}\mathrm{Mn} \\
\mathrm{Pb}\end{array}$ & $\begin{array}{c}\mathrm{Mn} \\
\mathrm{Fe}\end{array}$ & $\begin{array}{c}\mathrm{Mn} \\
\mathrm{Ni}\end{array}$ & $\begin{array}{l}\mathrm{Mn} \\
\mathrm{Cu}\end{array}$ & $\begin{array}{l}\mathrm{Mn} \\
\mathrm{Zn}\end{array}$ & $\begin{array}{c}\text { Mn } \\
\text { V }\end{array}$ & $\begin{array}{l}\mathrm{Cr} \\
\mathrm{Pb}\end{array}$ & $\begin{array}{l}\mathrm{Cr} \\
\mathrm{Fe}\end{array}$ & $\begin{array}{l}\mathrm{Cr} \\
\mathrm{Ni}\end{array}$ & $\begin{array}{l}\mathrm{Cr} \\
\mathrm{Cu}\end{array}$ & $\begin{array}{l}\mathrm{Cr} \\
\mathrm{Zn}\end{array}$ & $\begin{array}{c}\mathrm{Cr} \\
\mathrm{V}\end{array}$ \\
\hline-0.27 & 0.07 & 0.67 & -0.60 & 0.77 & 0.03 & -0.48 & -0.34 & 0.48 & -0.78 & 0.69 & 0.65 & 0.14 & 0.43 & 0.12 \\
\hline $\begin{array}{l}\mathrm{Pb} \\
\mathrm{Fe}\end{array}$ & $\begin{array}{l}\mathrm{Pb} \\
\mathrm{Ni}\end{array}$ & $\begin{array}{l}\mathrm{Pb} \\
\mathrm{Cu}\end{array}$ & $\begin{array}{l}\mathrm{Pb} \\
\mathrm{Zn}\end{array}$ & $\begin{array}{c}\mathbf{P b} \\
\mathrm{V}\end{array}$ & $\begin{array}{l}\mathrm{Fe} \\
\mathrm{Ni}\end{array}$ & $\begin{array}{l}\mathrm{Fe} \\
\mathrm{Cu}\end{array}$ & $\begin{array}{l}\mathrm{Fe} \\
\mathrm{Zn}\end{array}$ & $\begin{array}{l}\mathrm{Fe} \\
\mathrm{V}\end{array}$ & $\begin{array}{l}\mathrm{Ni} \\
\mathrm{Cu}\end{array}$ & $\begin{array}{l}\mathrm{Ni} \\
\mathrm{Zn}\end{array}$ & $\begin{array}{l}\mathbf{N i} \\
\mathbf{V}\end{array}$ & $\begin{array}{l}\mathrm{Cu} \\
\mathrm{Zn}\end{array}$ & $\begin{array}{c}\mathrm{Cu} \\
\mathrm{V}\end{array}$ & $\begin{array}{c}\mathrm{Zn}_{\mathrm{n}} \\
\mathrm{V}\end{array}$ \\
\hline 0.51 & -0.67 & -0.03 & -0.36 & -0.4 & 0.11 & -0.59 & 0.51 & 0.87 & 0.74 & 0.29 & -0.27 & -0.13 & -0.81 & 0.62 \\
\hline
\end{tabular}

\section{Number and Weight of Tar Balls :}

When crude oil is spilled or leaked from tankers. It undergoes a series of physical and chemical processes, such as spreading, evaporation, solvation, emulsification, dispersion, sedimentation, oxidation, biodegradation and formation of $\operatorname{tar}$ balls $^{[10]}$. As a net result of the weathering process, tar balls will be subjected to winds, waves, and tides, to be stranded near and above the high waterline. Tar balls then are thrown to the beach.

Table (6) shows the number of tar balls found in each site, together with weights of tar balls found. Individual tar balls were found to have weights ranging from 10.0 to $20.95 \mathrm{~g}$ and numbers of tar balls from 3 to 15 . Tar balls occurred in many physical forms. During the collection of samples, no fresh slicks were observed in the studied sites. The distribution of tar balls indicates old spills, the tar was laid as thin layer mats at the high water lines, and small weathered lumps exist near the high water lines, carried there by winds and currents. Tar was found stuck to the rocks in some sites, making it difficult to remove for analysis. Also, some tar was found mixed with sand, shell fragments and seaweeds, these were impossible to retrieve. 
Table (6): Density (number of tar balls per $\mathrm{m}^{2}$ ) and concentration (weight in grams of tar balls per $\mathrm{m}^{2}$ ) in Hadramout coast.

\begin{tabular}{|l|c|c|c|c|}
\hline \multicolumn{1}{|c|}{ Location } & No. of tar balls & Weight & Tar Conc. $\mathrm{g} / \mathrm{m}^{2}$ & No. $\mathrm{m}^{2}$ \\
\hline Broom & 7 & 18.3 & 0.0305 & 0.0116 \\
Al-mukalla & 3 & 10.0 & 0.0166 & 0.0050 \\
Al- Rayan & - & - & - & - \\
Al-habah & 4 & 12.7 & 0.0212 & 0.0066 \\
Al-Shaher & 15 & 20.95 & 0.0349 & 0.025 \\
\hline
\end{tabular}

\section{Trace Elements in Tar Balls :}

Potential release of ballast water and bilge oil from oil tankers that pass near the Hadramout coast are responsible for the stranded tar balls. Tar balls may have different compositions, but most of them contain paraffin, hydrocarbons up to $\mathrm{nC}_{40}$, oil sludge, non-volatile materials, resins, asphalten some trace constituents such as heavy metals ${ }^{[11]}$. Certain trace elements such as $\mathrm{Ni}, \mathrm{V}, \mathrm{Cr}$, and $\mathrm{Pb}$ are considered to be oil related ${ }^{[12]}$. Analysis was carried out for these trace elements, adding to them $\mathrm{Zn}, \mathrm{Fe}, \mathrm{Mn}, \mathrm{Co}, \mathrm{Cu}$, and $\mathrm{Cd}$. The concentration of each trace element in tar balls collected in each site along the studied Hadramout coast are presented in Table (7).
The mean concentration values for trace elements in tar balls expressed in ug/g are: 0.0.596 Cd, 2.540 Co, 0.884 Mn, 4.913 Cr, 5.353 $\mathrm{Pb}, 3.30 \mathrm{Fe}, 3.138 \mathrm{Ni}, 0.815 \mathrm{Cu}, 0.935 \mathrm{Zn}$, and $0.763 \mathrm{~V}$. The highest mean concentration value was $5.353 \mathrm{~Pb}$ ug/g, obtained at Broom and $\mathrm{Al}$ Dhabah. The second highest mean concentration value was $4.913 \mathrm{Cr} \mathrm{ug} / \mathrm{g}$ obtained at $\mathrm{Al}$ Dhabah and Al-Shaher. These high values may be influenced by several factors and reflect different sources. The results were subjected to linear regression analysis, and the correlation coefficients between trace elements pairs in tar balls are shown in Table (8), with high numbers for $\mathrm{Cd}-\mathrm{Zn}, \mathrm{Pb}-\mathrm{Cu}, \mathrm{Zn}-\mathrm{V}$.

Table (7): The Concentration of the trace elements in tar balls (ug/g) (dryweight).

\begin{tabular}{||l|c|c|c|c|c|c|c|c|c|c||}
\hline Location & Cd & Co & Mn & Cr & Pb & Fe & Ni & Cu & Zn & V \\
\hline Broom & 0.450 & 3.550 & 0.877 & 4.750 & 5.70 & 3.10 & 3.170 & 0.900 & 0.950 & 0.770 \\
Mukalla & 0.460 & 3.10 & 0.930 & 4.10 & 5.11 & 3.30 & 3.10 & 0.830 & 0.910 & 0.735 \\
Dhaban & 0.500 & 3.00 & 0.870 & 5.50 & 5.40 & 3.10 & 3.30 & 0.770 & 0.960 & 0.798 \\
Al-Shaher & 0.460 & 3.30 & 0.860 & 5.30 & 5.20 & 3.70 & 2.98 & 0.760 & 0.920 & 0.750 \\
Mean & 0.596 & 2.540 & 0.884 & 4.913 & 5.353 & 3.30 & 3.138 & 0.815 & 0.935 & 0.763 \\
Medium & 0.460 & 3.300 & 0.870 & 5.300 & 5.20 & 3.30 & 3.170 & 0.830 & 0.950 & 0.770 \\
\hline
\end{tabular}

Table (8) : Results of line regression analysis as correlation coefficients between trace elements pairs in tar balls

\begin{tabular}{|c|c|c|c|c|c|c|c|c|c|c|c|c|c|c|}
\hline $\begin{array}{l}\mathrm{Cd} \\
\mathrm{Co}\end{array}$ & $\begin{array}{l}\text { Cd } \\
\text { Mn }\end{array}$ & $\begin{array}{l}\mathrm{Cd} \\
\mathrm{Cr}\end{array}$ & $\begin{array}{l}\mathrm{Cd} \\
\mathrm{Pb}\end{array}$ & $\begin{array}{l}\mathrm{Cd} \\
\mathrm{Fe}\end{array}$ & $\begin{array}{l}\mathrm{Cd} \\
\mathrm{Ni} \\
\end{array}$ & $\begin{array}{l}\mathrm{Cd} \\
\mathrm{Cu} \\
\end{array}$ & $\begin{array}{l}\mathrm{Cd} \\
\mathrm{Zn}\end{array}$ & $\begin{array}{c}\text { Cd } \\
V\end{array}$ & $\begin{array}{c}\text { Co } \\
\text { Mn }\end{array}$ & $\begin{array}{l}\mathrm{Co} \\
\mathrm{Cr}\end{array}$ & $\begin{array}{l}\mathrm{Co} \\
\mathrm{Pb}\end{array}$ & $\begin{array}{l}\mathrm{Co} \\
\mathrm{Fe}\end{array}$ & $\begin{array}{l}\mathrm{Co} \\
\mathrm{Ni}\end{array}$ & $\begin{array}{l}\mathrm{Co} \\
\mathrm{Cu}\end{array}$ \\
\hline-0.78 & -0.82 & 0.82 & -0.09 & -0.32 & 0.69 & -0.62 & -0.99 & -0.66 & -0.29 & -0.12 & 0.64 & 0.87 & -0.34 & -0.68 \\
\hline $\begin{array}{l}\text { Co } \\
\mathrm{Zn}_{\mathbf{n}}\end{array}$ & $\begin{array}{c}\text { Co } \\
\text { V }\end{array}$ & $\begin{array}{l}\mathrm{Mn} \\
\mathrm{Cr}\end{array}$ & $\begin{array}{c}\text { Mn } \\
\text { Pb }\end{array}$ & $\begin{array}{c}\mathrm{Mn} \\
\mathrm{Fe}\end{array}$ & $\begin{array}{c}\mathrm{Mn} \\
\mathrm{Ni}\end{array}$ & $\begin{array}{l}\mathrm{Mn} \\
\mathrm{Cu}\end{array}$ & $\begin{array}{l}\text { Mn } \\
\mathrm{Zn}\end{array}$ & $\begin{array}{c}\text { Mn } \\
\text { V }\end{array}$ & $\begin{array}{l}\mathrm{Cr} \\
\mathrm{Pb}\end{array}$ & $\begin{array}{l}\mathrm{Cr} \\
\mathrm{Fe}\end{array}$ & $\begin{array}{l}\mathrm{Cr} \\
\mathrm{Ni}\end{array}$ & $\begin{array}{l}\mathrm{Cr} \\
\mathrm{Cu}\end{array}$ & $\begin{array}{l}\mathrm{Cr} \\
\mathrm{Zn}\end{array}$ & $\begin{array}{l}\mathrm{Cr} \\
\mathrm{V}\end{array}$ \\
\hline-0.38 & -0.16 & -0.91 & -0.43 & -0.07 & 0.04 & 0.34 & -0.56 & -0.59 & 0.22 & 0.13 & 0.24 & -0.61 & 0.60 & 0.72 \\
\hline $\begin{array}{l}\mathrm{Pb} \\
\mathrm{Fe}\end{array}$ & $\begin{array}{l}\mathrm{Pb} \\
\mathrm{Ni}\end{array}$ & $\begin{array}{l}\mathrm{Pb} \\
\mathrm{Cu}\end{array}$ & $\begin{array}{l}\mathrm{Pb} \\
\mathrm{Zn}\end{array}$ & $\begin{array}{c}\mathrm{Pb} \\
\mathrm{V}\end{array}$ & $\begin{array}{l}\mathrm{Fe} \\
\mathrm{Ni}\end{array}$ & $\begin{array}{l}\mathrm{Fe} \\
\mathrm{Cu}\end{array}$ & $\begin{array}{l}\mathrm{Fe} \\
\mathrm{Zn}\end{array}$ & $\begin{array}{c}\mathrm{Fe} \\
\mathrm{V}\end{array}$ & $\begin{array}{l}\mathrm{Ni} \\
\mathrm{Cu}\end{array}$ & $\begin{array}{l}\mathrm{Ni} \\
\mathrm{Zn}\end{array}$ & $\begin{array}{l}\mathrm{Ni} \\
\mathrm{V}\end{array}$ & $\begin{array}{l}\mathrm{Cu} \\
\mathrm{Zn}\end{array}$ & $\begin{array}{c}\mathrm{Cu} \\
\mathrm{V}\end{array}$ & $\begin{array}{c}Z_{n} \\
V\end{array}$ \\
\hline-0.63 & 0.34 & 0.92 & 0.79 & 0.60 & -0.9 & 0.26 & -0.69 & -0.36 & 0.15 & 0.82 & 0.82 & 0.25 & -0.12 & 0.96 \\
\hline
\end{tabular}




\section{CONCLUSION AND RECOMMENDATIONS:}

The present study has shown a significant increase in the concentrations of trace elements found in sediments, seawater, and tar balls, along the five studied sites on the Hadramout coast. Therefore, necessary steps have to be taken to limit if not stop the rising pollution by heavy elements.

Monitoring stations need to be established along the Hadramout coast, because it is one of the busiest coast when it comes to oil exploration and production. These monitoring stations can analyse seawater, sediments, and tar balls regularly. Therefore, they can start the alarm if pollution reaches hazardous levels. Also, can act as watchdogs for those oil tankers or local industries that dump their waste output into the sea, and endanger the marine wildlife along the coast. Those who break the Law of International Convention (MARPOL), must be apprehended and brought to justice. These are some of the measures that the government can start, to reduce pollution along the coast. Hence, marine wildlife which constitutes a major income for our country can be preserved.

\section{REFERENCES :}

1-Ba-Isa, A., Al-Shawafi, N., Marine Pollution along Hadramout Coast, 1999, unpublished, Personal communication.

2-Abdullah, M., Royle, L., A study of the dissolved and particulate trace metals in the Bristol Channel., Mar. Biol. Ass., U.K., 1974, 54, 581-597.

3-Smith, J., Butler, D.,Grant, B., Little, A., Millis, N., and Milire, P., Distribution and significance of $\mathrm{Cu}, \mathrm{Pb}, \mathrm{Zn}$, and $\mathrm{Cd}$ in the
Cairo-Bay ecosystem, Aus. J. Mar. Fresh Water Res., 1981, 32:151-164.

4-AWWA (1985). Standard Methods for the Examination of Water and Waste Water $24^{\text {th }}$ Ed. American Public Health, Washington D.C.

5-Al-Shawafi, N., Beach Tar along the Red Sea Coast of Yemen, Ph.D. thesis.1999, Fac. of Science, Sana'a Univ., Sana'a, Yemen.

6-Hassan, E., Systematic Evaluation of Selected Nutrients, Heavy Metals and Microbiol Pollution along the Coast of the UAE, J. Fac. Sci. UAE Univ., 1993, Vol. 8, No. 17.

7-Bryan, G., Pollution due to heavy metals and their compounds. Marine Ecology. Comprehensive Integrated Treaties on Life in Oceans and Coastal Waters. 1984, Vol. V, Part 3, A Wiley Inter. Sci. Pub.

8-Riley, J., and Chester, R., Introduction to Marine Chemistry, $1^{\text {St }}$. Ed. Academic Press. London. 1971.

9-Thomas, R., The distribution of Mercury in sediments of Lake Ontario. Can. J. Earth. Sci., 1972, 9, 636-651.

10-The International Tanker Owners Pollution Federation Limited (ITOPFL),1996. Staple Halls Stone House Court, 87-90. Houndsditch, London EC3A 7AX, U.K.

11-Butler, J., and Morris, B., Petroleum Residues in the Saragasso Sea and Bermuda Beaches. Proceedings of the Joint Conference on Prevention and Control of Oil Spills,1973, Am. Petrol. Inst. (API), Washington D.C., USA.

12-Fowler, S., Readman, J., Villenuve, J., and Mackay, K., Petroleum Hydrocarbons and Trace Metals in Nearshore Sediments and Biota before and after the 1991. War: An assessment of Temporal and Spatial Trends. Marine Pollution Bulletin, 1993, 27, 171-182. 